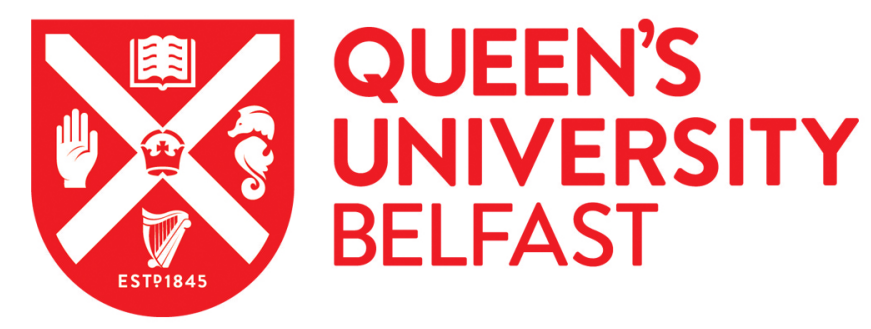

\title{
Dickens and the Codebreakers: The Annotated Set of All the Year Round
}

Litvack, L. (2015). Dickens and the Codebreakers: The Annotated Set of All the Year Round. Dickens Quarterly, 32(4), 313-337.

\author{
Published in: \\ Dickens Quarterly
}

Document Version:

Publisher's PDF, also known as Version of record

Queen's University Belfast - Research Portal:

Link to publication record in Queen's University Belfast Research Portal

Publisher rights

(C) 2015 The Dickens Society

\section{General rights}

Copyright for the publications made accessible via the Queen's University Belfast Research Portal is retained by the author(s) and / or other copyright owners and it is a condition of accessing these publications that users recognise and abide by the legal requirements associated with these rights.

Take down policy

The Research Portal is Queen's institutional repository that provides access to Queen's research output. Every effort has been made to ensure that content in the Research Portal does not infringe any person's rights, or applicable UK laws. If you discover content in the Research Portal that you believe breaches copyright or violates any law, please contact openaccess@qub.ac.uk. 


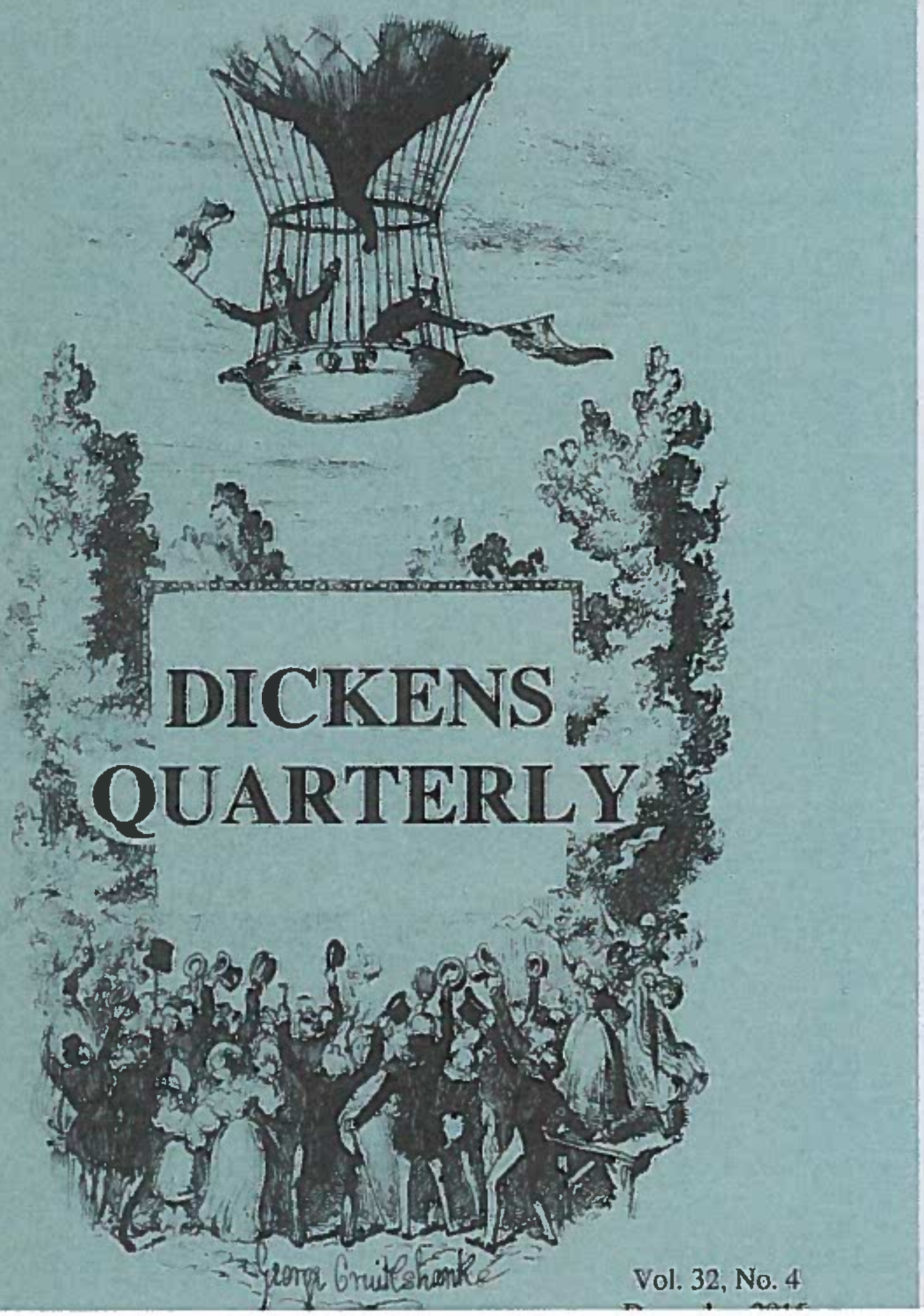


A seholarly journal devored to the scudy of the life. times, and works of Chadies Dickens

Dickens Quiarterly (ISSN 0742-5473)

Juhns Aopkins University Ptoss

2715 North Chasles Srreat

Baltimore, MD 21218

jrnlcirc@pressjbu.edu
DICKENS QUARTERLY

Volume 32 December 2015 Number 4

CONTRIBUTORS TOTHIS ISSUH

\section{ARTICLES}

September and Degember for the Diakens Sucien by Johns Hopkins University Press, $2715 \mathrm{~N}$. Charles Streer, Baltimore, MD 21218-4363, USA. The joumal began as Dickens Sudies Nensletter in 1970, the organ of the Dickens Sociaty. A new series took over in March 1984, when the title changed ro Dickens Quatrterly.

Srbsariptions; Rates for subscriprion may be found and orders may be placed at the following web addres: www.press,jhu.cdu/joutnals/diekens_ quarterlyl

Alt orders, address changes, and other business correspondence should be addressed to Johns Hopkins University Press, Journals Division, P.O. Box 19966. Baltimore, MI) $21218-4363$ (USA); telephone (410) 51.6-6987; Bax (410) 516-3866; email jrnleirc $(9)$ press.jhu.edu; on toll free 1-800-548-1784 (US and Canada onlv); www.press. hu.edu/journals. Claims for replacement of missing issues must be received within thre months of maiting (six months for foreign addresses). All notices of ohange of address should provide both ric old and new address.

POSIMASTER; Send address changes to Dickels Quarterly, Johns Hopkins Universicy Press, Journals Division, 2715 N. Chartes Streer, Baltimore, MD $21218-4363$.

Joumal indexing information may be found at htrp://ww'veress.ihu.edu/ jouruals/dickens quarterly/indexing. html.

The paper in this publication meets the requirements of ANSW NISOZ39.48-1942 (Permanence of l'apep).

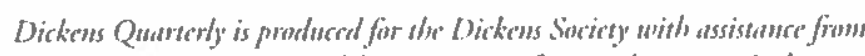

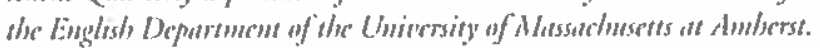

Copprighlu 2015 by the Dickens Soxiety
Willian l: Loug and l'aul Sillicke: A Work Definitely Not by Bor?

Ruth Richtardson: The Subterrancan Topography of Oliner Tisist

Leon Litvack: Dickens and the Codebreakers: The Annotated Sit

REVILWS

Neil Forsydu on: Mary Hammond: Charles Dickenss "Great Expectations": 338 A Crillinal Life, 1800$)-2012$

Ben Moore on: Matthew Reramomt: Nighnwhlking: A Nocummal History of London

Hazel Mackenzic ont: Cattherine Delaticld: Sorialiastion and the Nonel in Mid-Virturian Magazimos

THE FOKIY-SIXTH DICKENS SOCIETY MELTING AND BUSINESS

NOTICISS

THE DICKENS CHECKLISI: - Clare Horrocks and

Kim I:dwards Keates 
David Paroissien, Geneml Editor

Trey Philpotts, Revietw Editor Amanda Helm, Production Editor Claire Horrocks and Kim Edwards Keates, Bibliographers

Dickens Quarterly is edited by David Paroissien, Emeritus Professor of English, the University of Massachusetts, Amlterst. Articles and Notes for publication and all editorial correspondence, including queries about advertising rates, should be sent to the editorial address supplied below:

\author{
David Paroissien \\ 100 Woodstock Road \\ Oxford OX2 7NE, England \\ Email address: <paroissien@english.umass.cdu>
}

Contributors: Please submit one typescripc copy to the editorial address above and a Word file (.doc or .docx) to paroissien@english.umass.edu. Typescripts will not be returned unless accompanied by a self-addressed envelope and the cost of return postage, either in pounds sterling or in International Reply Coupons. For detnils about DQ house style, footnotes, textual references and other citations, please see the journal's website <dickensquarterly.org>

Revicws: The review pages are edited by Professor Trey Philpotts, Department of English, University of Arkansas at Litele Rock, 2801 S. University Avene, Litele Rock, AR 72204. Book reviews are commissioned and it is unlikely that we will accept unsolicited contributions.

Permissions: (C) 2015 by The Dickens Sociery. All rights reserved. No portion of Dickens Quarterly may be reproduced by any process or tedinique without the formal consent of the publisher. Copies for personal or internal use may be made on the condition that the copier pay a fee of $\$ 8.00$ per copy through the Copyright Clearance Center, 222 Rosewood Drive, Danvers, MA 01970, for copying beyond that permitted by Section 107 or 108 of the U.S. Copyrigbr Law. This consent does not extend to other kinds of copying, such as copying for general distribution, for advertising or promorional purposes, for creating new collecrive works, or for resalc. (0742-5473). Direct all other permissions requests to the Jolıns Hopkins University Press Rights \& Pcrmissions department at www.press.jhu,edu/cgi-bin/ permissions.cgi.

The full text of Dickens Quraterly is available electronically through Project Muse: http://muse.jhu.cdu/journals/dickens_quarterly. Contact <musc@press.jluu.cdu> or Tcl. 410-516-6989.

\section{Contributors to this Issue}

Leon Litvack is Reader in Victorian Studies ar Queen's University, Belfast. He is Principal Editor of the Charles Dickens Letters Project, and is editing Our Mutual Friend for the Clarendon Dickens series.

William F. Long is Emeritus Professor in Biochemistry at the University of Aberdeen. He has published several articles for The Dickensian and Dickens Quarterly and contributed to the Oxford Readers'Companion to Dickens.

Nancy Aycock Metz is Professor of English ar Virginia Tech. She has published a number of articles on Dickens and Victorian literature and is the author of the Companion to 'Martin Cluzzlewit'(2001). She is ctirrently working on the Pickwick volume in the Dickens Companions series.

Ruth Richardson is a Fellow of the Royal Hisrorical Society, and Senior Research Fellow at the Cencre for Life-Writing Research, King's College, London. She is also a Past President of the Dickens Society. She is author of Death Dissection and the Destitute (2000), Vintage Papers from The Lancet (2006), The Making of Mr Graj's Anatomy (2008) and Dickens and the Workhouse (2012).

Paul Schlicke was Senior Lecturer in English at the University of Aberdeen until retirement in 2010. His Clarendon edition of Sketclies by Boz is preparing for publication. 
Forster, John. Life of Clurrles Dickens. Ed. J. W. T. Lcy. London, Palmer, 1928. The Gazettc official Public Record/London Gazettc: https://www, thegazette.co.uk Kitton, Frederick George. Dickens and lis Illussrators. London, Redway, 1900. Old Bailey. hetp://wwwoldbailcyonline,org/ Case of Emmal Luke, August 1836. Old Bailey. hetp://wwwoldbaileyonline.org/ Case of Jolun Roach, September 1829. Psiropoulos, Brian: "Hortense is no Esther: Dickens' Anagrams". Notes of Queries 2013: 265-6.

Richardson, Ruth. Death Dissection and the Destitute. London: Routledge, 1987.

—. The Making of MIr Groy's Anatomy. Oxford: OUI, 2008.

- Dichens and the Workhouse. Oxford: OUP, 2012.

—. "Young Mt Dickens's Calling Card" Dickens Quarterly' 28, 1 (2011): 65.

- "Charles Dickens and the Cleveland Street WorkJouse". Dickens Quarterly 28.2 (2011): 99-108.

— and Brian Hurwitz. "Joseph Rogers and the Relorm of Workhouse Medicine". Brivish" Medical Jourmal (16 Dec 1989) 299: 1507-1510.

Rogers, Joseph. Reminiscences of a Workhouse Medical Officer. Ed. Thurold Rogers. London, Fisher Unwin, 1889.

Spitalficlds Life: spitalficldslife.con1/20 $13 / 06 / 09 /$ /at-chatles-dickens-childhood-home/ Survey of London XLVIII. London, London Councy Council, 1949.

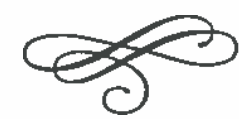

Dickens and the Codebreakers: The Annotated Set of All the Year Round

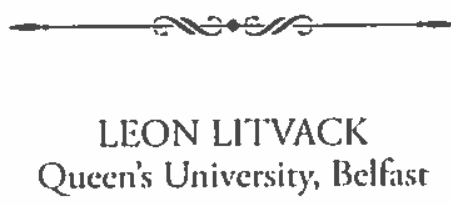

Queer's University, Belfast

$\mathrm{O}$ 7 May 2015 a "secret" mecting took place in Senate House. University of London, between two Dickens scholass, a Wilkie Collins specialist, and an English antiquarian book dealer (sec Dugan). The purpose of the gathering was to authenticate a series of carcfully inscribed annotations in a handsonely bound set of All the Yatr Rornind, the journal which Dickens edited from 1859 until his death in 1870) (see Drew, Dickens the Joumalist 137-57). "The bookseller, Jeremy P'arrott, had purchased the enenty volumes unseen, from an online dealer in Wrexhinn, north Wales, in September 2014. The three specialists who met Parrott (Michacl Slater, Jolin Drew, and Paul Lewis), and had a bricf opportunity to examine a number of sample volumes, canue away convinced thate the marginalia, which identified by name the authors of each of the individual pieces, were genuinc. Later that month Michael Slater contacted me, and shared a number of digital photographs (reproduced here) of the annotations; he asked $\mathrm{me}$, in my role as the Principal Editor of Dickens's Letters, if I thought the entries were genuine, and whether or not $I$ could confirm that the handwriting was Dickens's own.

"The implications of this discovery are huge for Dickens scholars, als well as for those who study the host of authors - numbering berween three and four hundred - who wrote for this journal. The names of some contributors have long been known; they include Edward Bulwer-Lytton, Wilkie Collins and his brother Charles, Percy Firzgerald, Elizaberh Gaskell, Sheridan Le Fanu, Charles Lever, Eliza Lynn Linton, Henry Morley, Adelaide Procter, Charles Reade, George Augustus Sala, Walter Thormbury, Frances Trollope and Edmund Yates (see Oppenlander 250-99 and Dickens Journals Online). Some, like Wilkic Collins, were easily identified by contemporaries, because their installments of serial fiction carried stuch uncnerypted titles as "NO NAME. BY THE AUTHOR OF 'THE WOMAN IN WHITE, \&c." In orher cases, though, no record of authorship has survived; this newly discovered annotited set of the First Series of $A / /$ she Vear Rotmd las 
introduced into the circle of contributors such well known figures as Lewis Carroll, and has also expanded the range of pieces penned by Gaskell, Wilkie Collins, and Dickens himself (see Dugan and Milmo, "Charles Dickens revealed").

Up until now, in the case of $A l l t h c$ Year Round, a great deal of detecrive work has been employed to establish authorship of many of the individual picces. The reason for this situation is that we do not possess a resource like the "Office Book" for Household Words. That indispensable volume, meticulously compiled by Dickens's sub-editor, W. H. Wills, surfaced in 1903, and now resides in the Morris L. Parrish Collection at Princeton Universicy. It identifies the author(s) of each article published during the nine-year run of the journal, and provides details of the date of payment, amount paid, and other relevant data. The Office Book is rightly judged by Anne Lohrli to be "rhe only trustworthy record of Household Words contributors" (Lohrli 43); it formed the basis of her authoritative reference work, which has proved of inestimable value to researchers of Victorian periodicals (see Drew and Craig 267-8). It may be safe to assume that Wills, who managed "all aspects of the Commercial Department and much of the Literary work" for All the Year Round (Drew, Dickens the Joumalist 137) also kept an Office Book for the later journal; if it still exists, its whereabours are unknown.

There is, however, a record of another source: a so-called "'office' ser." One of the founders of the Dickens Fellowship, Frederic George Kitton (author of such indispensable carly works as Charles Dickens by Pen and Pencil) compiled a discursive bibliographic history entitled The Minor Writings of Charles Dickens (1900). In his preface he stared that his work represented "the compilation of a complete list of Dickens's ephemeral contributions to periodical literature, notably to those journals of which he himself was editor"; he added that

With respect to All the Year Round my task was simplified owing to the Fact that, by great good-fortune, I discovered in the possession of $\mathrm{Mr}$. W. H. Howe an 'office' set of that journal, in which has been inseribed against each article, etc., the name of the author thereof - satisfactory and conclusive proof as to its origin. (Kitton vi, vii; for details on Howe sec Drew and Craig 287)

Kitcon consulted this resource some time between 1895 and 1900 . He was only interested in documenting the contributions to the journal by Dickens, and he had his list "endorsed" by author's son Charlcy, who was taken on as general manager and sub-editor towards the end of Dickens's life (Letters 12: 378). It is curious to note that in compiling his House/sold Words listing, for this same Minor Writings volume, Kitton only relied on "internal cvidence" and Charley's assistance (in the wecks before the latrer's deatly; sec Kitton 123) - even though the Office Book for Dickens's first journal was then in the hands of Wills's niece, Eliza Priestley (see Lohrli 35).

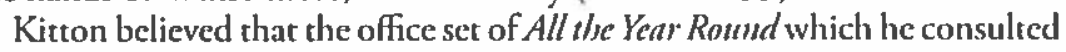
was annotated by "a member of the printing staff" (Kitton 138); bur if this were so, irs purpose is unclear. Copies of $A$ ll $t /{ }^{\prime}$ Year Rotund were sold from the journal's office at 26 Wellington Street (Fig. 1); Drew and Craig suggest the possibility that an office set was kept and compiled by those staffing the slıp, "to answer enquiries from customers about authorship." They also make several other useful observations:

It was elearly sufficiently detailed to discinguish between the authors of scparate short paragraphs of jointly-authored items such as the 'Occasionial Register' in $A Y R$ 's first issue [sec Kitron 142 and Oppenlander 64́, 262], buse can we be sure that this degree of granularity was maintained throughout the 24 bi-annual volumes published under Dickens"s editorship? If an article were based on a recent publication and loosely 'crammed' by a member of the writing staff, would its compiler's name be recorded as aurhor, or that of the author of the book being reviewed? When the writer of a serial novel was given in print at the statt of each installment as 'by the author of,' did the printers bother on every occasion to inscribe the author's name against it, and if not, what orher omissions may there have been? Questions such as these, more or less unanswerable, start to crowd in. (Drew and Craig 269)

Thus even if the office set exists, it may not be possible to unravel all the mysteries concerning authorship in All the Year Rownd.

The drive towards anonymity in his journals was clearly important to Dickens, as he indicated to Elizabeth Gaskell in January 1850:

No wricer's name will be used - neither my own, nor any others - every paper will be published without any signature; and all will seem to express the general mind and purpose of the Journal, which is, the raising up of those that are down, and the general improvement of our social condition. (Letters 6: 62)

Though he eventually modified this strategy - particularly with respect to his own serial fiction - he pressed consistently for the development of a powerful, unified identity, communicated through a fusion of voices into a single entity, which he initially termed "a certain SHADOW, ... a kind of semi-omniscjent, omnipresent, intangible creature," which, he said, "may go into any place ... and be in all homes, and all nooks and corners, and 
be supposed to be cognisant of everything, and go everywhere, without the least difficulty" (Letters 5: 622). There were risks inherent in this initiatrive - particularly for promising young writers; Elizabeth Barrett Browning, commenting on the consequences for $\mathrm{R}$. H. Horne of collaborating on journalistic pieces with Dickens, wrote to her friend Mary Russell Mirford in 1851: "Dickens's name would swallow up every sort of minor reputation in the shadow of his path. I shouldn't like, for my part (and if I were a fish) to herd with crocodiles" (see Letters 6: 451). Yet Dickens undertook from the outset to "give established writers the power of reclaiming their papers after a certain time," so that they could be republished elsewhere (Letters G: 39); this privilege was later extended to minor authors as well (Drew, Dickens the Journalist 118 ). It is also important to note, as Drew does, that Dickens considered the absence of a contributor's signature to be a stage in his or her quest for an audience; "anonymity," Drew adds, "went hand-in-hand with salcs-boosting speculation about atuthorship" (Dickens the Joumalist 183 , 151). The sales of All the Yeur Round, which remained steady at 100,000 a week (Oppenlander 49) - despite some occasional dips (see Patten 286-7, on Lever's $A$ Day's Ride) - were, perhaps, sufficient evidence that identifying the writers was not the contemporary readers' overwhelming concern.

Dickens aimed for editorial consistency in his two journals, as he, assisted by Wills, his able "friend" and "other self" in journalistic matters (Letters 7: 694) strove to provide the reading public with a steady stream of stimulating material, including original poetry and fiction; observations on social issues some controversial - which could facilitate political agitation; and articles on an encyclopaedic range of subjects, from popular science to popular fashion and ancient history to life in the colonies (see Drew, Dickens the Journalist 115-6). Yet it would be inaccurare to clain that the opinions expressed in all of the individual pieces accorded with Dickens's own views; there are, for example, contrary sentiments in some of the contributions by Harriet Martineau to Houselsold Words, such as "How to Get Paper," published on 28 October 1854; Dickens bemoned of it ro Wills: "Rather a gloomy No. Miss Martineau pretry well, but grimly bent upon the enlightenment of mankind, and quite absurdly overdoing American Education" (Letters 7: 438; see also Drew, Dickens the Journalist 124-5). Despite such instances of dissent, Dickens was steadfast in his claim of edirorial integrity - most explicitly and publicly in All the Year Round, a journal which experienced lis gradual disappearance from its pages, from 1863 onward (see Drew, Dickens t/uc Jotmalist 151). In December of that year, at the conclusion of Charles Reade's Hard Cas/, he published a statement outlining the latitude he granted to those who contributed original fiction to the journal; but the memorandum opened with this assertion, in block capitals: "THE STATEMENTS AND OPINIONS OF THIS JOURNAL GENERALLY,
ARE, OF COURSE, TO BE RECLIVED ASTHE STATEMINTS AND OPINIONS OF ITS CONDUCTOR" (Dickens, "Note" 419).

Shu-Fang Lai cites these words in an article which ponders what can be learned about Dickens - and his hundreds of contributors - from his periodicals. In arguing that Dickens's serutiny of his journals was nor ats assiduous as scholars have ofren claimed, she observes that "we cill almost never be sure about deducing Dickens's own opinions from articles written by his contributors unless we have external evidence." She also motes that we must "make a discriminating reading of each article in the light of its author and its context if we are ro deduce Dickens's opinions on the topics in his journals" (Lai 41,50). Thus knowing the identity of each and every contributor is essential to our acquiring the fullest possible understanding of the subject at hand, and the stance taken towards ir. In thinking about my own past research on Dickens's views of Ireland and the Irish (sec Litvack), I realize how much richer that study might have been, had I been able ro confirm the identities of the authors of such pieces in $A / l t / h_{e}$ Year Round as "The Irish Convict's Progress," concerning the superiority of the Irish prison system over the English one; "Irish Stew," which includes reminisecnces on the historical events which inspired Dion Boucicault's play Zllse Collecu Bann: "Thuggee in Irelind," which describes the supposedly violent tendencies of Irish "pensant-assissins;" and "A Recent Lounge in Dublin," which features a rather theatrical description of the trial of some of the Fenian leaders, who had been accused of high treason (for extended analysis of these pieces see Lirvack 7-9). Because there was no way to breal the code of anonymity, I had to collecr instead those scraps of evidence buried, for example, in Dickens's correspondence. Concerning "A Recent Lounge in Dublin" he observed to his friend Samucl Lover: "Wrirer of Irish story of Diableric, unquestionably Irish" (Letters 11: 128). More than that it was impossible to say.

In the wake of Oppenlander, significant new research has proposed Dickens as the author of several unascribed journal istic pieces in All the Year Round. In 1997 John Drew published a convincing analysis of an article from 1863 entitled "Dress in Paris." He cites relevant biographical evidence, and passages from the author's correspondence; to these he adds a decailed consideration of phrasing in the article, which is "reminiscent of Dickens's mature journalistic style," as well as observations abour Dickens"s skill as an interpreter of cultural difference (Drew, "Charles Dickens, Traducteur?"). $\mathrm{He}$ is thus able to offer the considered opinion that Dickens is probably the author of the piece. Drew (this time in collaboration with Hugh Craig) also proposed Dickens as the author of anorher piece in All the Year Romd. entitled "Temperate Temperance," concerning the unnecessiary scrutiny of the English working man's habits - particularly his consumption of beer. In that study, entitled "Did Dickens Write 'Temperate Temperance'?" the 
authors employ traditional methods similar to those used in the "Traducteur" piece, but add to them the power of computational linguistics - in particular the "Burrows Method," developed at the Centre for Literary and Linguistic Compuring in Australia - to transform a scholar's "hunch" abour authorship into a "statistically acceptable possibility" (271). The method relies on the establishment of signature profiles for a range of possible authors of a particular anonymous text; it then compares known texts by these authors to the unatributed one under scrutiny (see Drew and Craig 274-82). The rests lead the authors to assert that "Temperate Temperance" is "a perfectly genuine piece of vintage Dickens editorial;" they also envisage an expanded use of this merhodology, to discern wherher the authors of other anonymous pieces in All the Year Round may be confidently identified. Scholars will readily appreciate how much effort has been expended in these two test cases developed by Drew and his colleagues to establish authorship beyond reasonable doubt. The recent discovery of the annotated set - if substantiared by further careful scrutiny - has the potential to revolutionize research on All the Year Round.

Jeremy Parrot broke the news of his fortuitous discovery on Saturday 11 July 2015 in Ghent, Belgium, at the annual conference of the Research Society for Victorian Periodicals (RSVP). The title of his paper was "The Contributors to All the Year Round: A Victorian Mystery Solved. "On 13 July Patrick Leary of the RSVP posted a message on the organisation's websice; part of it read as follows:

Scholar and bookdenler Jeremy Patrott revealed at RSVP, for the first time anywhere, his discovery of a 'marked ser' of All the Year Round. This hitherto unrecorded 'deluxe edition' in scarlec binding has handwritten marginalia identifying (almost) all of the contributors by name, next to each one's contribution. Between 300 and 400 contributors of some 2500 articles, stories, and poems, are now conclusively identified for the first time. As if this were not exciting enough news, experts like Michael Slater and John Drew have been able to confirm that many of these annotations are in Dickens's own hand. In his paper, Dr. Parrott made a persuasive case that this was Dickens's own personal set of the magazine, probably kept in his private office at the magnzine's offices in Wellington Street.

The atmosphere in the room when Dr. Parrott delivered his news was electric. As this group of scholars knows better than any other, a 'marked set' of any Victorian magazine is an extremely rare and precious thing.

The presentation at the RSVP certainly caused a stir - not only in the scliolarly community but also in the media. By 13 July Parrott was in England, and three London papers carried the story that day. The Guardian's Alison Flood called the discovery a "lucky coincidence that would not look out of place in a Charles Dickens novel;" she also recorded the recollections of Parrotr (who identified himself as "enough of a Dickens scholar to realise this was a huge find") as he opened each of the volumes:

At first I spotted Percy Firzgerald, who I knew was a tong-time Dickens collabotator. I thoughe 'that's interesting, I wonder if it was by him'....

Then I siw Henry Morley, Wilkic Collins, Mrs Linton ... then the second or third volume I opened had a Cliristmas story in it, and looking in the margin of the Christmas story, I thought, hang on, this isn't just a name, this is Dickens's signature. And that was the 'oh my God' moment, when I thought this isn't just an annotated set, it is Dickens's own set. (Flood)

Partott expanded on these comments in a radio interview with John Wilson on 14 July, for BBC's Front Rotv program. He had brought volumes 1 and 3 of the journal to the studio, and as they were opened on air, the conversation progressed as follows:

Wilson: Just give us a sense of what happened when you opened the bubble wrip first, to see what youid got. ... So we have a fadied red, nicely embossed cover there. ...

Parrott: So when I got this set, and saw - oh - beautiful set, opened it up, lec's see what's in it, and then ... you see, in the margin ...

Wilson: And so ... in pencil there, does it siy 'J. Parkinson'?

Parrotr. That's right. ... Joseph Parkinson, who was one of Dickens's known contributors, but it's not known that he wrote that.

Wilson: There's another one there; that one s.yys ...

Parrott. Dickens' writing, hard to decipher; it's actually 'Mr. Dodd,' who was a science writer for him. There's a 'Mr. Bromley' here. ... There's another one: 'Percy Firzerald,' who was one of Dickens' young men, and he was a well-known contributor. Every page it tells you who wrote what. So this was volume one of ewenty, and then a mad scrabble to get to the next volume, and the next volume, and the next volume, and in fact when I got to the third volume of the twenty - and I have the third volume - this is the third one that I looked at; I opened it up. I don't know if you can read that.

Wilson: No, I cant; what docs that say?

Parrott: It's actually the signature of Charles Dickens. ... I compared this with known signatures of Dickens; tny goodness! (Parrott, intervicw by John Wilson)

Most of these contributors are already known entities, though Parkinson's first confirmed contribution - unti] now - to All t/sc Year Round dates from 1865 (see Oppenlander 285). George Dodd was not known - until 
now - to have contributed to All t/se Year Round, thought he did write 65 articles for Houselsold Words between 1852 and 1857 (sec Lohrli 262-3). Percy Fizgerald's authorship of many pieces had already been declared in his Roman Candles (1861) and Memories of Clartles Dickens (1913), and documented in Oppenlander (266-9), though it is possible that these annotations reveal him to be rhe author of other, previously undocumented pieces. "Mr. Bromley" is not a known contributor to either of Dickens's journals, so careful rescarcl will need to be done to confirm who he is; he may be Sir Richard Madox Bromley (1813-66), the Accountant-General of the Navy, whom Dickens mentions several times in correspondence (see Letters 9: 188, 316,553), though the appellation "Mr." would not seem to fit, unless the entry was not made by Dickens, which is a possibility.

One figure whose name kept coming up in the newspaper reports of Parrort's discovery was Wilkie Collins (see Milmo, "Charles Dickens revealed," Dugan, McAloon, Flood, and Sulcas). He was not only one of the "corps" of the Dickens's contributors; he and his editor exercised mutual influence on one another, in both their "novelistic and journalistic aestheric" (Drew, Dickens t/sc Jourmalist 119, 144; see also Nayder). The Collins connection was especially emphasized in a BBC radio interview for the World at One on 13 July. The presenter, Edward Stourton, spoke to Paul Lewis (already mentioned above), who is Secreary of the Wilkic Collins Society. After the annotations were described in general terms, Stourton asked: "So you've been going through them all and looking out which ones ... your mans ... Wilkie Collins did." Lewis replied:

Well, indeed. I've seen four of these volumes [at the 'secret' meeting referred to at the start], and it's very neat pencil notes by every item. ... Within [the volumes] there are eight new pieces by Wilkic Collins. ... They ... are workiday writing - one about how we should pay postmen properly, one about the state of dheatres, one a very sidd picce about someone who died on a Polar expedition, and they are a very interesting addition to his canon. (Lewis, interview by Stourton)

The pieces Lewis refers to in this interview ate "Hear the Postman!", "Managers and Music Halls" (borh from 1861), and "The Last Leaves of a Sorrowful Book" (from 1859). Another newly discovered piece by Collins, "The Crusoe of the Snowy Desert," was mentioned in the Independent's coverage of the find (see Dugan).

Paul Lewis has been instrumental in establishing the authenticity of the annotations in this set of All the Year Round. Despite some misleading comments by journalists, suggesting that all the annotations were all in Dickens's "own handwriting, revealing who wrote everything" (Dugan; sec also Sulcas), the reality is more complex. At the meeting with Parrot in Senate House, Lewis rook photographs of a selecred number of irems - mostly those which concerned Collins. $A$ selection of pieces for which Dickens's friend is the sole atributed author include "The Dead Lock in Italy" (Fig. 2, already known to be written by Collins; sec Oppenlinder 180), "Managers and Music-Halls" (Fig. 3, mentioned above), and "The Sentiments of Martha Jones" (Fig. 4, another newly atrributed picce). Lewis was also able to substantiate, using Parrott's annotated set, that Collins was the author of the "The Seafaring Man," the fourth chapter of "A Message from the Sea," the journal's Christmas story for 1860 (Fig. 5; see Oppenlander 94). Beside the fifth chapter of "A Message from the Sea," which carries the ritle "The Restitution," there appears in the annotated set the names "Chas Dickens \& Wilkic Collins" (Fig. 6). While this collaborition hetween the wo authors had previously been established (see Oppenlander 94 and Stonc $530-1$ ), the question of who entered these attributions in the margins is an extremely interesting one. Lewis has uscfully compiled an image which compares five occurrences of "Wilkie Collins" in the annotated set between 1860 and 1866 (Fig. 7). These attributions may then be compared with Dickens's own writing of Collins's name ( $\mathrm{Fig} .8$ ), to see if they match, The evidence indicates that they do not: Dickens has a distinctive way of writing the eapital "W," and the lower case leterer " $k$," particularly when followed by an "i." Also, the way in which he characteristically composes the capital "C" does not feature the serif (or curl) at the top, which is evident in Figures 2, 3, 4, 5 and 6 . These annotations are not, therefore, by Dickens; nor are they in the hands two other likely candidates: W. H. Wills or Charley Dickens (the latter worked on All the Year Round from 1868 onward; sec Drew, Dickens the Jou'nalist 156-7). Samples of their handwriting do not mattel the annotitions in this set.

Lewis also took a phorograph of a curious annotation featuring the name "Charles Dickens" (Fig. 9), and confirming him as the author of the cighth chapter of "Dr. Marigold's Prescriptions," entitled "To Be Taken for Life" (see Oppenlander 166 and Glancy 437-8). Ar first glance it would appear to be Dickens's own hand, with a flourish below the signature; however, a comparison with other Dickens holograplus of the 1860s (Fig. 10) indicattes that this entry is an imitation of Dickens's signature rather than an actual one (for further comments on Dickens's evolving signature sec Letfers 1: xxiv and accompanying plate). The key incongruitics in the marginal annotation in the Parrotr set may be seen in the formation, for cxample, of the capital " $\mathrm{C}$ " which in the genuine signature consists of an inirial stroke forming a forward-facing loop, followed by a downstroke running into a second loop. The "k" of the genuine signature consists of a vertical covering stroke followed by an angle; the annotation, on the other hand, forms at 
" $\mathrm{k}$ " by means of a vertical covering stroke, followed by a closed loop. As for the final "s," in the authentic signature it is a simple loop, leading into in forward and backward-running covering stroke; in the annotation the " $\mathrm{s}$ " is formed by a more complex loop, the final stroke of which curves into a small backward-facing loop below the baseline, and then threading into a Hourish. The genuine Dickens flourish is clearly detached from the signature, while in the annotation it is firmly connected (for further insight into the analysis of handwriting, and an explanation of the terms used here, sec Jacoby and Nezos).

This brief graphological comparison of the annotation and the authentic signature might give the mistaken impression that the Parrott set could be al forgery. It should be cmplasized, however, that none of the experts consulted in the verification process (myself included) has suggested that the annotated volumes are anything bur genuine. Parrotr has claimed in interviews that there are entries in Dickens's hand (sec Parrote, interview by John Wilson, as well as McAloon and Flood); but the entries considered here are clearly by others, and to date I have not seen a single marginal note which can be confirmed as being by Dickens. There are also orher factors militating anginst many of the annotations being by the author; they include his long sojourn in America in 1867-8, and his absences on reading tours in Britain and Ireland (see Andrews 275-90). One interesting set of innotations, however, points to a private system of referencing, which could only have been conceived by Dickens, probably as a private joke. These concern the author Frances Eleanor (Fanny) Trollope, who is referred to as "Aunt Margaret" in the marginalia. She was married to Anthony Trollope's brother Thomas, and was also the sister of Ellen Ternan; Fanny had been an actress, but was "the one member of the family who had not acted with Dickens" (Slater 18). The appellation "Aunt Margaret" is part of the tirle of her short narrative ("The Tale of Aunt Margaret's Trouble"), published in July-August 1866 in six weckly installments (for her other previously known contributions see Oppenlander 296-7). In the Guardian article on the annotated set, Michael Siater reasoned that "Instead of writing Fanny Trollope as the name of the contributor, [Dickens] writes Aunt Margaret, as though he's deliberately disguising the fact that this is Ellen's sister;" the reason, Slater deduces, is that Dickens is "disguising the fact that he pays lier a pretty good rate, because he doesn't want it known," on account of his own relationship with Fanny's sister (see Flood; see also Slater 161).

In the initial media reporting of the discovery of the annotated set, a good deal of attention was paid to the expanded list of female contributors to All the Year Round. In a radio interview on 16 July for the BBC World Service, Parrotr highlighted the new attributions to Hesba Stretton (the pscudonym of Saral, Smith), Eliza Lynn Linton, and Elizaberh Gaskcll. All of these authors are known to have contributed to All the Year Ronnd (sec Oppenlander 292-3, 279, 269); but Parrort's comments imply that it is now possible to identify many more pieces by these writers (Parrotr, interview by Dan Damon). Gaskell, for example, is revealed to have atuthored at twopart essay in 1864, entitled "Old, New, and No Music," which offers it comparison berween German and English compositions (sec Dugan, who incorrectly refers to Gaskell's "pair of articles on French song and poetry").

In the same World Service interview, Parrot opened up volume 17 of the journal in the studio, and pointed the presenter to the piece entitled "What is Sensational?" He said: "You call probably see in the margin here, we've got the names Charles Dickens and J. Parkinson, and this is a previously unatrributed Dickens article" (Partott, Interview by Dan Damon). 'The piece was reprinted in full in the Independent, with the following prefatory remarks:

One of the most spectacular essays - an attack on a complacent establishment that could colerate the appalling state of poor relief - had previously been aturihuted to one Joseph Parkinson, atnd presumed on be only a commission from the great man of letters. But from the newly studied margin notes, it now secms that Dickens not only supplicd the idea but was chief autbor of the polemic. Below, we publish the piece ... which remains a great example of passionare reporting; still relevaut, still an inspiration to anyone who sees their role as giving a voice to those who cannot be heard. (Wills)

The newspaper takes this opportunity to demonstrate the effectiveness of the piece's rhetoric, and the continuing relevance of Dickens's journalism in the twenty-first century; but the reporter, Kate Wills, adopts the unambiguous stance that Dickens was the "chicf author," and thus devalues the contribution of Parkinson, who was an Inland Revenue Clerk, in the Accountant and Comptroller-General's Department, and was sufficiently in Dickens's confidence to help him to clear up the affairs of his younger brother Alfted, who died in I860 (see Letters 9: 283, 285: 10: 440). The reality behind the collaboration between Dickens and Parkinson is, thus. probably mucls more complex than a simple margiual annotation suggests. Indeed in a letter of April 1866, Dickens wrote to his contributor to saly that he thought "all the subjects" submitted by Parkinson to be "good," and that even in the case of one, "Derby Dregs," which he finds "least promising," Dickens admits "I may not carch it from your point of view" (Letters 11:180).

The question of how involved Dickens, W. H. Wills, or other members of staff were in both explicitly collaborative pieces and in other contributions which were revised in various degrees before publication, is a fascinating one. Jolun Drew insightfully points to the "polygraplyy" of individual 
picces; this term implies a "compounding" of "many different writers and writings together in an anonymous miscetliny" (Drew "An Uncommetcial Proposition" 303). "This concept is perhaps best illustrated by reconsidering the two journalistic pieces - "Dress in Paris" and "Temperare Temperance" - whose authorship Drew worked hard to establish, as itndicated above. In botly cases Drew demonstrated that the balance of evidence suggests Dickens as the writer; but when I isked Jeremy I'arrote to consult his annotated set, in order to test Drew's conclusions, he kindly replied that the margiualia confirm the authors to be Edmund Saul Dixon (for "Dress in Paris") and Charles Allston Collins (for "Temperate Temperance"). Parrott atso confirmed that Dixon was "one of the most prolific contributors across 20 volumes" of All t/se Kar Round, while Charles Collins "made over 100 contributions" (I'arrott, "Re: All the Yeat Rotrirl"). Up to now, Dixon had never been confirmed as the author of any piece in All the Yat Round, though he was a prolific contributor to Houschold Words (sec Lohrli 256-61). Some of Charles Collins's contributions had heen established previously (sec Oppenlander 253-6), but they amounted to nowhere neat the number confirmed by Parrott. This new information does not, however, discount of invalidate the research by Drew. If the concept of "polygraphy" is a valid onc, then it might well be the case that Dickens had a hand in writing or revising "Dress in Paris" and "Tcumperalte Temperance" before publication. If we recill the principles of the "Burrows Method," descriled above, then it is evident that in the trials conducted on "Temperate Temperance" Drev and Craig employed a relational strategy: the computational linguistic analysis reveals whose aurhorial sryle a pice of unknown authorship mos resembles. The rest samples employed by Drew and Craig included writings by Dickens, Wilkic Collins, Henry Morkey, Edmund Ollier and W.H. Wills. and a "signature" profile was established for each of these atuthors (Drew and Cratig 274). If samples by Charles Collins (the established author of the piece) were added to this mix, it would be interesting to see what results would emerge.

These two cases of revised attribution open up - rather than close down - many more possibilities for research involving rhe annotated set of $A l l$ the Yerr Round. Some insightful comments about the effect on scholarship were made in the radio interview berween Edward Stourton and Patul Lewis:

Stourton: So this is like cracking a code. ... It 's cxtratordinary. I mean, once youve got this you can find out all sorts of things.

Levis: Yes; I mean ... it's like the Rosteta Sene in literature

Stourton: Or the l:anigm

Lenvis: Well, yes. ... I mean, you kindly silid I was in dle audience [in Ghent, and so ] was just silting flece listeniug to Jerenty giving his great

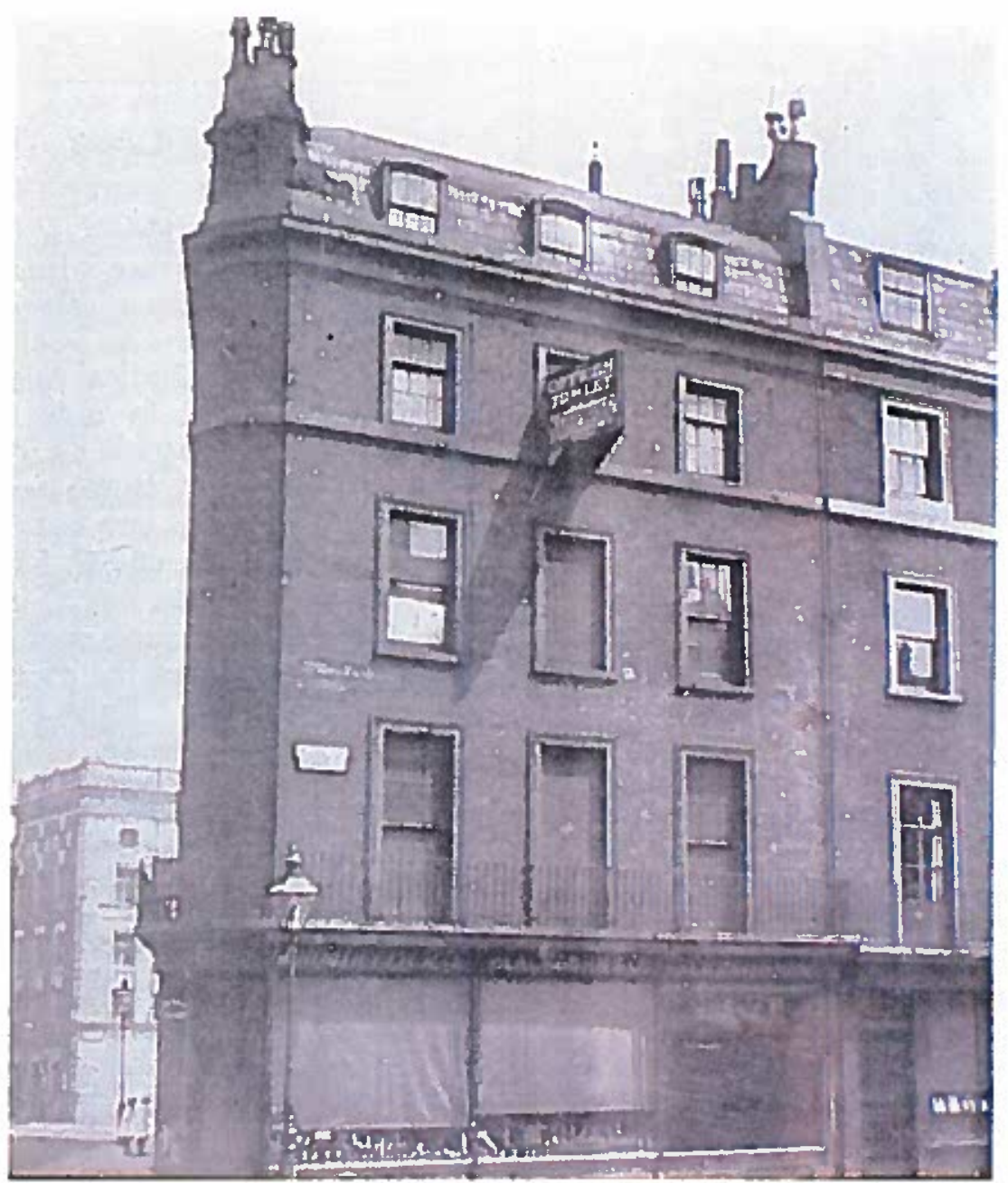

Fig. I: An early 20th-century photograph of the offices of All t/se Year Round, 26 Wellington Strect, London. The ground floor functioned as a shop, from which customers could purchase the journal. By kind permission of the Charles Dickens Muscum 

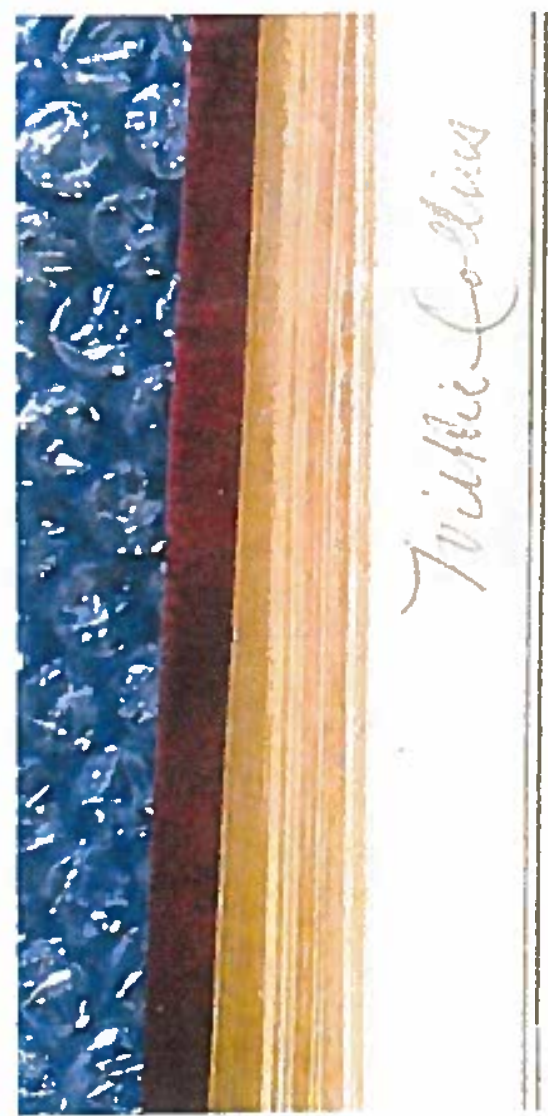

fitissct.

THE DEAD LOCK II

a IETTER fROy AN EsGIISIIM AN ITALIAY IN LO: - . "You are visiti fourtl time. You liave leisut mancl, you liave cyes in jout sympathics in the Italian que libcrul side. Rome is now chatrese wich maty be lelt all or mine, in my exilc, liow liome lon

This very natural refuest me, ny groud fricnd, on the fift jol: In onc calcudar montle li French troops are hound, unde to leave tle Pope and the l'oos differences torrether. Mrust I liome looks, inder these ciro pere foneself to be astonjshe self to be disapuointed. Irom looked when I was here last, I since-ass liome louked when the seennd time, eleven seats lookel, when I was here, fo

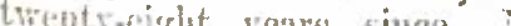

Fig. 2: Marginal annotation identifying "Wilkic Collins" as the author of "The Deid Lock in Italy," All the Yeur Round 16 (8 December 1866): 510 By kind permission of Paul Lewis.

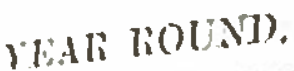

cConduotod by

wor or civilised min, who would bave told me lor that Pimbliotionk wns my corliest pation and

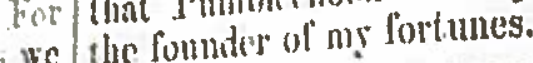

his MANAGLIS $\Lambda$ ND MUSIC-HALLS.

uter

it "Hons they do inree on the stage, their fret matumity is wonderful."

ins T"he nimagers of the Loudon thentres havo

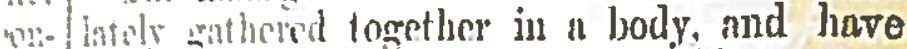
a T uffered to the olservation of the public a pracni ficnl commentiy on Sheridan's ndmirable text. itil bit this occasion, the motive for monamous ur. agrecment amonis these gentlemen las boen

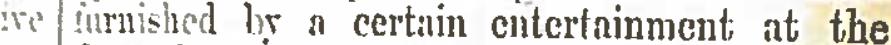
su Conerbur Music-Ilull, Loudon, mlich bears a ack suspicins ly close resemblance to the representatron of a pantomime. Aur performance of this of. sort-if if takes place out of a theatre-or any ue. jerformance at all which involves the intercu change of dialoguc betreen actors (cven when Ire ther nre only tio in number) is vicwed bv the

Fig. 3: Marginal annotation identifying "Wilkie Collins" as the author of "Managers and Music Halls," All the Year Round 4 (23 March 1861): 558. By kind permission of Paul Lewis. 


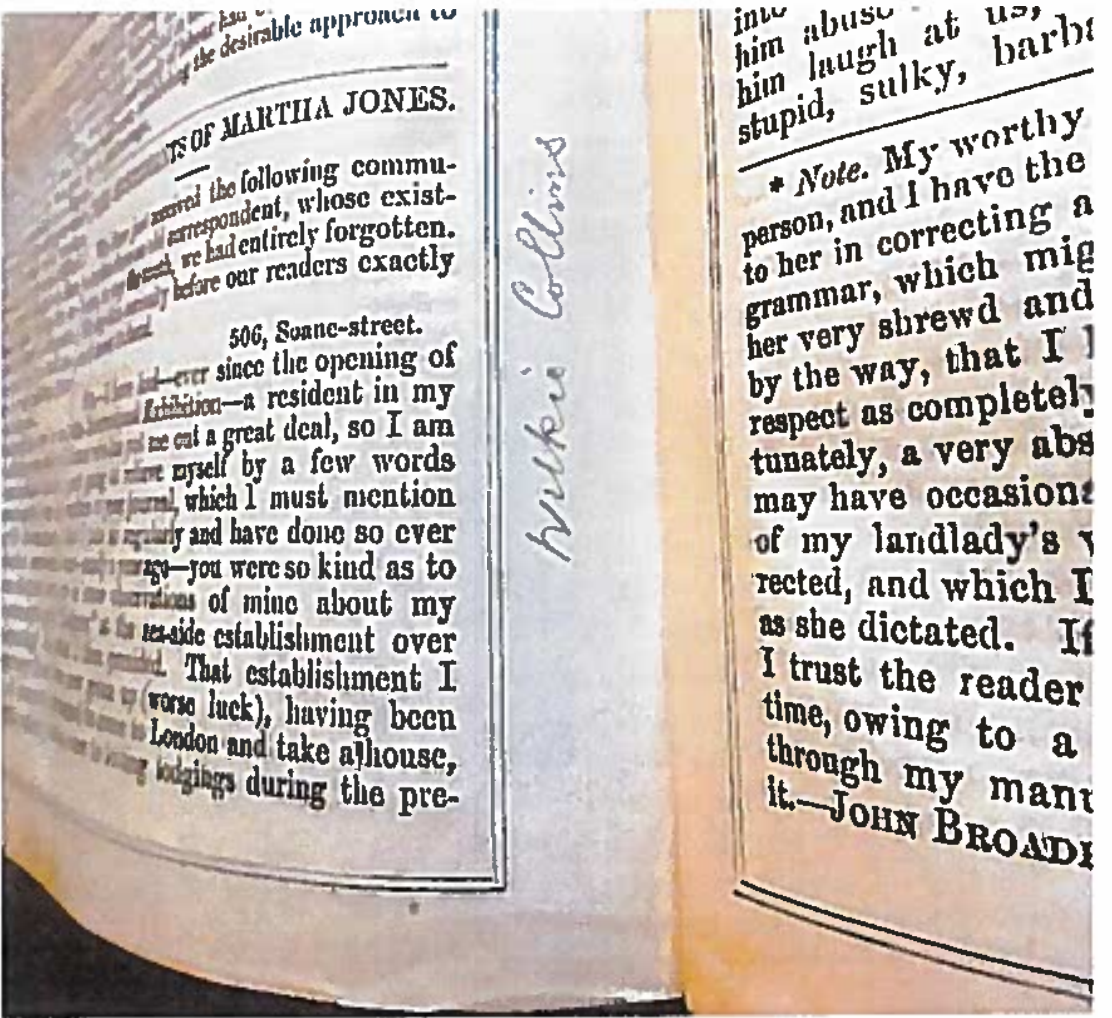

Fig. 4: Marginal annotation identifying "Wilkic Collins" as the author of "The Sentiments of Martha Jones," All t/se Year Round 7 (26 July 1862): 472.

By kind permission of Paul Lewis.

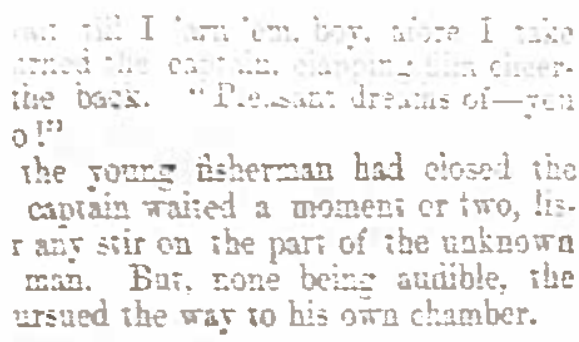

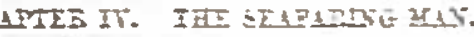

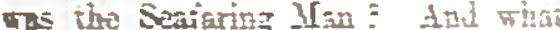

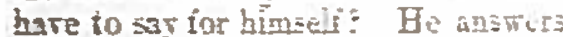

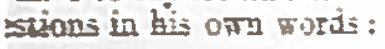

3 by mentioning wis: happers on $\mathrm{mt}$ northrand, from Falmonith in Cors. Srepprets in Derogshire. I lare no to say (being tere) that it brought me to Lamrean. I kad bysiness in hate as part ret semons, and partín as ext jorth ind this basiness, jou will erg jeaneber, was the cause of $\mathrm{mI}$

arding at F-month, I tretelled on foot; of tise expenus of rition, and bocanse 1 (c)

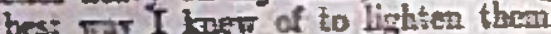
bes: 91 to

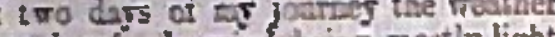
and scht, ine wien bello moatly light

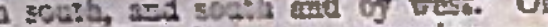
A dat, I tock a mrong varaing, and

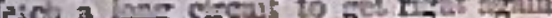

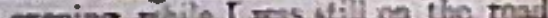

Fig. 5: Marginal annotation identifying "Wilkic Collins" as the author of chaper 4 of "A Message from the Sea," All the Year Round Extra Christmas Number 4 (13 December 1860): 31.

By kind permission of Paul Lewis. 


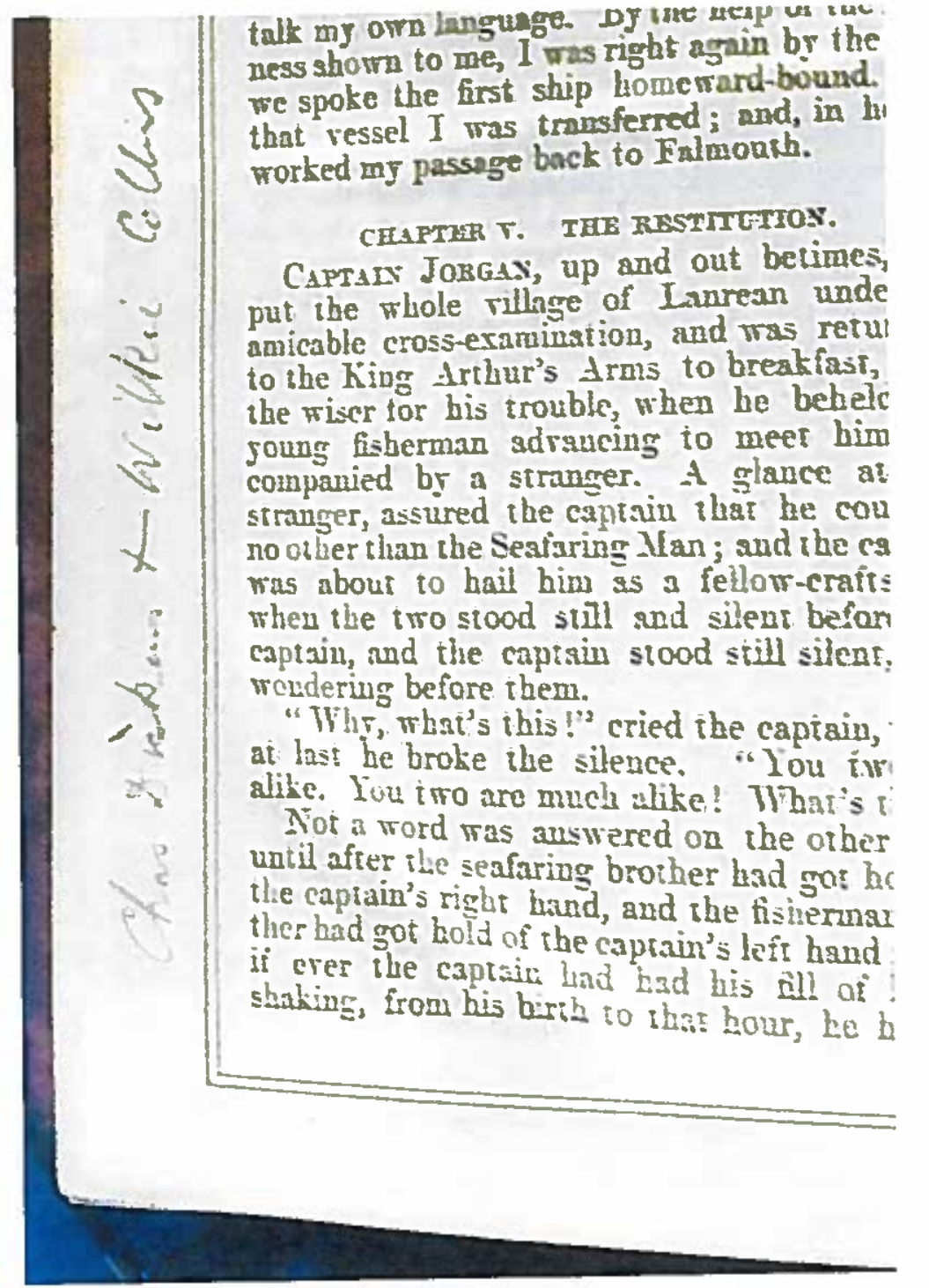

Fig. 6: Marginal annotation identifying "Chas Dickens \& Wilkie Collins" as the authors of chapter 5 of "A Message from the Sea,"

All the Year Round Extra Chrisemas Number 4 (13 December 1860): 44. By kind permission of P'aul Lewis.
1860

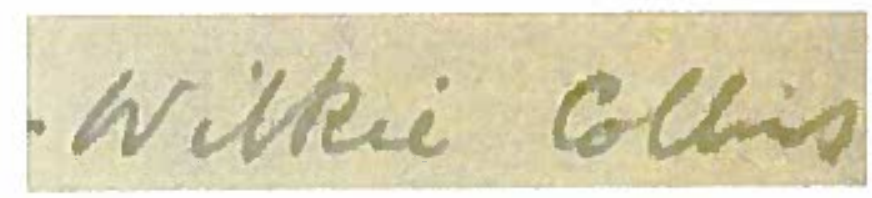

1860

1861

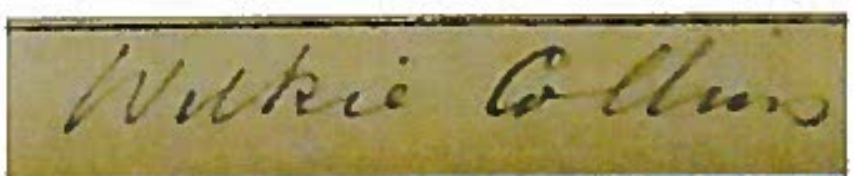

1862

1866

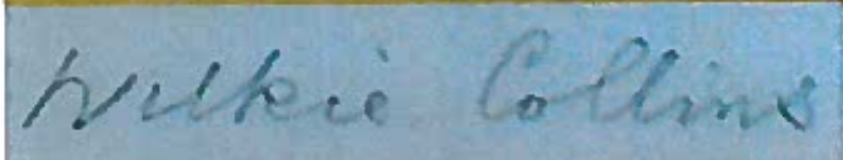

Fig. 7: Comparison of five occurrences of "Wilkie Collins" in the annotated set, between 1860 and 1866. By kind permission of l'aul Lewis.

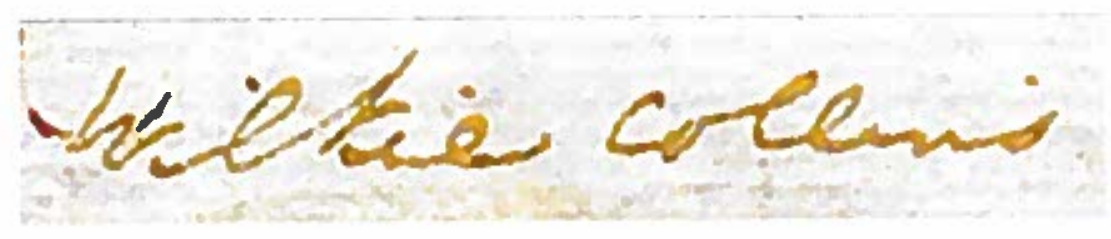

Fig. 8: An authenticated example of Dickens's writing the name "Wilkic Collins," cut out from al letter of the mid-1850s. By kind permission of Paul Lewis. 


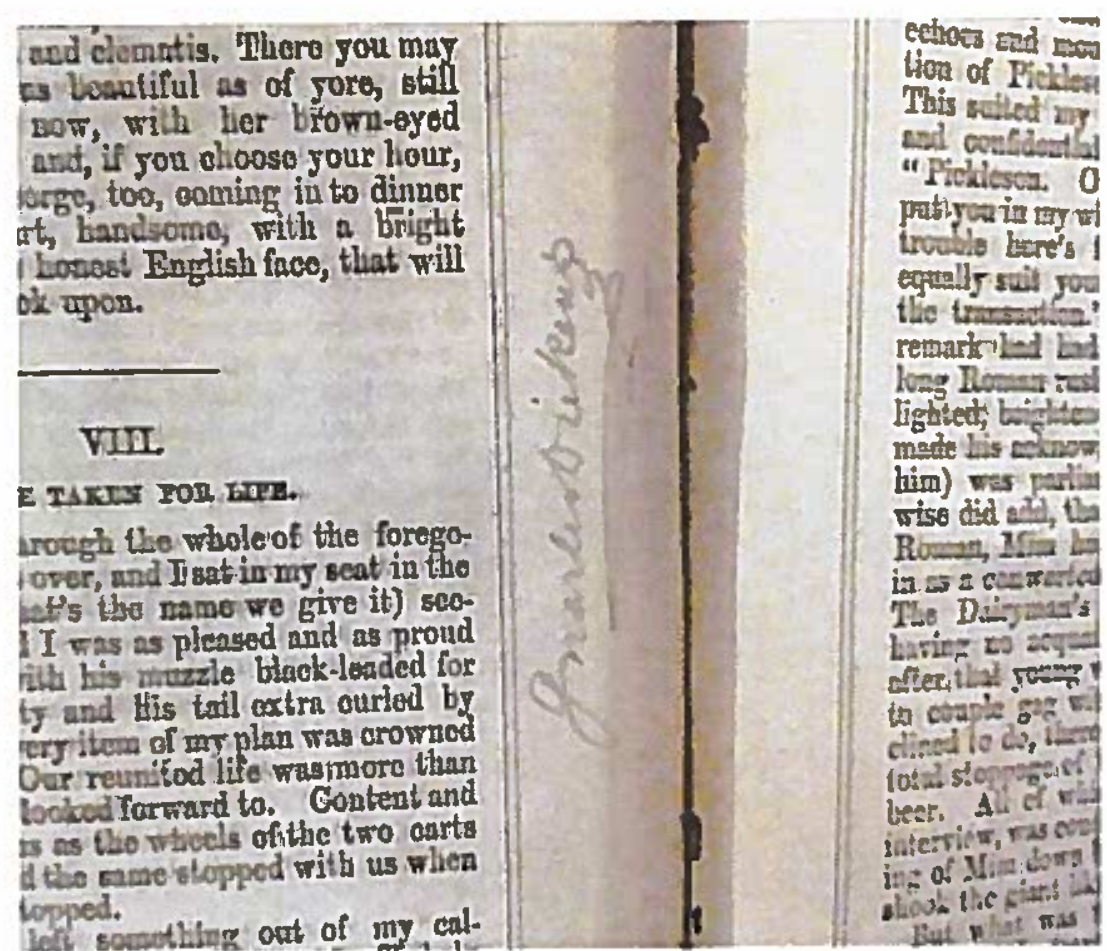

Fig. 9: Marginal annotation identifying "Charles Dickens" ats the author of "To Be Taken for Life," chapter 8 of "Dr. Marigold's Prescriptions," All the Year Round 14 Extra Christmas Number (7 Decenber 1865): 46.

By kind permission of Paul Lewis.

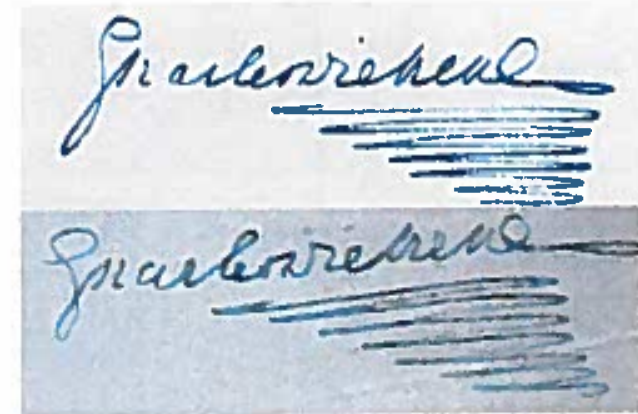

Fig. 10: Authenticated Dickens signatures from letters to W.D. Morgan, dated 6 February 1861 (top) and 19 March 1868 (bottom).

By kind permission of Robin Morgan Lloyd. revedation, but the we was all attdible gasp as he revealed this [of these lorty or fify Victorian specialists, becitust they knew that their work will never quice be the same inguto. (Lewis, interview by Siourton)

The comparison to nhe Rosetra Stome is instructive (see also McAloon). That granodiorite slath from the Ptolemaic period, featuring a thrice-inscribed decree, was intended for three distinct readerships: the hicroglyphs were for the priests; the Gireck was for the administraturs; and the demotic was the vernacular, to be used for more mundane purposes (see R. Parkinson). The coverage of Parrotes extraordinary find has followed a similar pattern. The various media outlets, which rushed to break the story, have provided the vernacular interpreation, which has been sensational, largely secking highlights, and inevitably producing a number of misconceptions. In the wake of this initial excitement, the more informed pronouncements about the annotated ser, or more carefully considered use of the material (which might be likened to an administrative or "priestly" use by Dickensians and other interested parries) will emerge, as details of authorship trickle ont, and as l'arrott moves towards his ultimate aim: the publication of at "complete contributors' list to $A / /$ the Year Rom $/$ " (Barrote, interview by Wilson; sec also Milmo, "Charles Dickens' nores")

This preliminary anilysis of a Victorian Eniggma has perhaps taised more questions than it has answered, and there are isstes soncerning the matcrial artefiacts which would merit further exploration. For instance, relatively litrle is known about the provenance of what Parrott hats called "Dickens' personal deluxe set" (Flood), bound in red doth with gilt edges (McAlooon). Slater has speculated that it was a "file set, probably kept in the Ilat Dickens load above the office of the periodical," for eitsy reference (sece Flood). Parrotis initial idealistic vision of Dickens, "in a few idle moments in a working day, sitting there and writing who wrote what in the previous month's issues" (Flood), is clearly an overstancment - particularly given that the amotations reproduced here are in other hands; nevertheless it may be saffely assumed

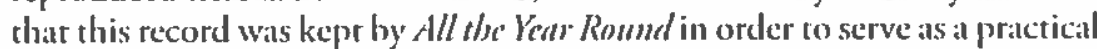
atde memoire of who wrote what in the journat. What is also unclear is what happened o these volumes once they lefe the Wellington Street ollice. They were probably sold atier Dickens's death by the fanily of his son Charley, whose own financial circumstances had become preciarious (sec Adrian $158-(99)$. By the 1920s the set had found its way into the possession of at wealthy North Willes family named Dutton; when the contents of their home recently went up for privite sale, it was bought by the Wrexham hooksellers, who sealed the deal with Parrort (see Dugan and Flood).

"There are other mysteries concerning the mitcrial arreficts which are yet to be solved. It is clear that the set in l'arrotr's possession is not the "alfice' set" 
referred to by Kitton (138; see also Drew and Craig 287-8), who does nor, for example, include among the pieces "written in collaboration with others" the article "What is Sensutional?", co-authored with Joseph Parkinson. The whereabouts of this particular set are unknown, and there is no chance of recovering it at present, given available evidence. A more promising prospect, however, exists, in the form of the contributors' book for All t/se Year Round, which was last heard of in 1945. At that time, William Miller (author of The Dickens Student and Collector and Honorary Librarian to the Dickens Fellowship) wrote to Leslie Staples, Editor of the Dickensian, as follows:

Yes, the contributors' book of 'All the Year round' exists. ... About 10 ycars ago we heard who had the book \& [Walter] Dexter made enquiries of the owner what he wanted for it \& he replied $£ 450$ would buy it, since then it has gone to America but who has it I cannot say. (Miller, Letter in Leslie Staples)

Walter Dexter was a bibliophile, a prominent founding member of the Dickens Fellowship, and preceded Staples as editor of the Dickensian. It would scem from the correspondence that the initial inquiry by Dexter was never followed up with the British owner of the contributors' book; it was rhen sold to an individual or institution in the United States sonse time in the period $1935-45$. If this is in fact the case, then it is possible that the volume still exists; if it can be found, its contents could be compared to what appears in Parrott's annotated set, in order to provide further confirmation of the authorship of individual pieces.

One final question concerning the set is, perhaps, the most difficult to address: irs monetary value. When I was intervicwed by the Chief Reporter of the Independent, Cahal Milmo, on 13 July 2015, he was very keen for me to pronounce on this issue. I studiously avoided this question, for two reasons. Firstly, I had only seen a small porrion of the available evidence, and I could not confirm that the volumes featured marginalia in Dickens's hand. Also, I did not wish to influence the eventual ownership of the volumes; Parrote has said that he might consider a sale, but only after his own scholarly work on the set was complete. Milmo did publish a figure; but ir was an erroncous one, based on the presumption that the entries were in Dickens's own hand (Milmo, "Charles Dickens' notes"). The only value I could anree to - both at the time of my interview by Milmo and now - is the one which did in the end appear in print; I said:

This is probably the most important find for [Dickens] scholars in my liferime. It gives us an insight into the links berween Dickens and other authors, whose names have been all too ofen lost in the mists of time.
It will be of inestimable value to scholars. (Milmo, "Charles Dickens revealed")

I am grateful to Hilda Sim, Michael Slater, John Drew, Paul Lewis, and Jeremy Parrott for their kind assistance in the preparation of this article.

\section{WORKS CITED}

Adrian, Arthur A. Georgina Hogarth and the Dickens Circle. London: OUP, 1957. Andrews, Malcolm. Charles Dickens and His Performing Scless. Oxford: OUP, 2006. [Collins, Char]es Allston]. "Temperate Temperance." All the Year Round 9 (18 April 18(3): 188-9).

[Collins, Wilkic]. "The Crusoc of the Sinowy Desert," All the Year Romel 1 (7 May 1859): 44-8.

[-]."The Dead Lock in ltaly: From an Englishman in Rome, w an Italian in London." All she Yoar Round 16 (8 December 1866): 510-4.

(-). "Hear the Postman!" All the Year Round 5 (6 July 1861): 366-8.

[-]. "The Last Leaves of a Sorrowful Book." All she Yat Round 1 (30 July 1859): 318-23. [-]. "Managers and Music Halls." All s/se Yenr Roumd 4 (23 March 1861): 558-61.

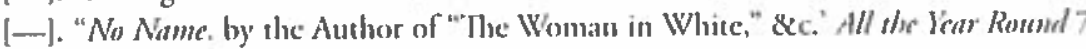
(15 Marcls 1862): 1-9)

[-]."The Seafaring Man." All the Yeor Round A. Extra Clristmas Number (13 December 1860): 31-44.

[-1."The Sentiments of Martha Jones." All the Yar Rotand 7 (26 July 1862): 472-6. Dickens Jonruals Online. Web.

Dickens, Charles. The Letters of Clwrles Dickesis, ed. Graham Storey et al. 12 vols. Oxford: Clarendon, 1965-2002

-. "Note." All the Year Round 10 (26 December 1863): 419.

[-1. "To be Taken for Lifc." All /he Year Round 14. Extra Christmas Numler (7 December 1865): 46-8.

[Dickens, Charles, and Joseph Parkinson]. "What is Sensational?" All the lear Romel 17 (2 March 1867): 221-

[Dickens, Charles, and Wilkie Collins]. "“The Restiturion." Al/ the Year Rormd A. Extrit Christmas Number (13 December 1860): 44-8.

[Dixon, Edmund Saull. "Dicss in P.aris." All the Kear Round 9 (28 Fehruary I863): 7-12. Drew, John. "Charles Dickens, Traducteur? A New Arricle in All the Year Round." Dickensiam 93.2 (1997): 116-25.

—. Dickens the Jourtulist. Basingstoke: Palgrave Macmillan, 20003.

-. "An Unconmercial Proposition?: At Work on Household Words and All the Veat Roustd" Victorian Periodicals Review 46.3 (2013): 291-316.

Drew, John, and Hugh Craig. "Did Dickens Write 'Temperate Timperance'? (an Attempt 
to ldentify Authorship of an Anonymous Article in all abe Yoar Round)." Victorian Periodicals Review 44.3 (20) 1): 267-90.

Dugitu, Emily. "Charles Dickens' notes solve the mystery of unidentified Victorian authors." Independent 13 July 2015. Web.

Firzgeralal, Percy. Mcmories of Charles Dickens, wish an Accontu of 'Honselsold Words' and 'All we Year Romed' and Contribusors Thereto. Bristol: J. W. Arrowsmith, 1913. - Roman Candics. London: Chapman and Hall, 1861.

Flood, Alison. "Dickens's marginalia reveal famous contributors to his journal." Grandiatn 13 July 2015. Wel).

[Giskell, Elizaberh]. "Old, New, and No Music. In Two Chaypters." All the Year Round 12 (22 October, 5 November 1864): 260-4, 294-300.

Glancy, Ruth 1: Dickens' Christmas Books, Clrristmats Stories, and Other Short Fiction: An Annotated Bibliography. New York: Gialland, 1985.

"Illiberal Doctors." All the Year Rornd 8 (7 leb. 1863): 519-21.

"The lrish Convicr's Progress." All the Year Round 8 (20 September 1862): 31-7.

"Irish Stew" All the Year Round 10 (7 November 1863): 256-8.

Jacoby, H. J. Amblyis of Handuriting: An Introduction into Scientific Gitphology. London: G. Allen \& Unwin, 1939.

Kitton, lirederic G. The Minor Writings of Charles Dickens: A Bibliograply and Sketds. London: Elliot Stock, 1900.

Lai, Shu-Fang, "Fet Or Fancy: What Cinn We Learn about Dickens from His Periodicals Housclsold Words and All she Your Round?" Victorian Periodicals Revicw 34.1 (2001): 41-53.

Leary, Patrick. "RSVP 2015 Conference in Glient makes international news." 13 July 2015. Web.

Lewis, Paul. Interview by Edward Stourson. 7he World at One. BBC Radio 4, 13 July 2015. Ridio.

Litwack, Leon. "Dickens, Ireland and the Irish Part II." Dickeusian 99.2 (2003): 6-22. Lohrli, Annc. Houselsold Words: A Weckly foumal 1850-1859 Conducted by Charles Dickens. Toronto: Toronto UI? 1973.

[Martineatu, Hatried]. "How to Get Paner." Houselold Words 10 (28 October 1854): $241-5$.

McAloon, Jonathan. "Charles Dickens's Anmotations Reveal the 'Rosetra Sione' of Victorian Literature." Telgraph 13 July 2015. Web.

Miller Willian. The Dickens Student and Collector: A List of Writings Relating to Charles Dickens and His Works, 1836-1945. Cambridge: Hasvard UP, 1946.

—. Letter to Leslie Staples. 27 July 1845. In the possession of Michad Stater.

Mímo, Cal al. "Charles Dickens' notes have solved a crucial scholarly guestion - but where will the valuable volumes end up and how much are they worth?" Independent 17 July 2015. Web.

—. "Charles Dickenes revealed ats author of essay defending 'sensational' newspaper reporting." Independem 13 July 2015. Web.
Nayder. Lillian. Unequal Bartners: Chatrles Dickens, Wilkic Collins, and. Victorian Authorship. Ithaca: Cornell UP, 2002.

Nezos, Rennia. Gmplology: The Imerpretation of Handrurissng. London: Century, 1986. Oppentander, Ella Aun, Dickens'All she lear Rousud: Descriptite Index and Comstribusor List. Troy, N.Y.: Whitston, 1984́.

[Parkinson, Joseph]. "Derby Dregs." Al/ the Year Romud 15 (2 June 1864): 487-9.

Parkinson, Richard B. Concking Codes: The Rosenta Stone and Decipherment. Londen: British Museum l'ress, 1999.

Paurot, Jeremy. Interview by Dan Damom. World Updatr. BBC World Service, 16 July 2015. Radio.

-. Inerview by John Wilson. Front Rou. BBC Radio 4, 14 July 2015. Radies. —. "IRe: All the Year Round," Message wo Leon Litvack. 28 September 2015. Eimail. Paten, Robere L. Charles Dickens and H/is Problishers. Oxford: Clarendon, 1978.

"A Recent Lounge in Dublin." All the Year Rotuth 14 (23 December 1865): 516 6-20. Slater, Michacl. The Great Clartes Dickens Scandal. New Haven: Yale UP, 2012

Stone, Harry. "Dickens Rediscovered: Some Lost Writings Recrieved." NinescenthCentury Fiction 24.4 (1970): 527-48.

Sulcas, Roslyn. "A Trove of Forgoten Writings is found in a Periodical Edited by Dickens." Nesu lowk Times 13 July 2015. Wetr.

"Thuggee in Ireland." Al/ t/c Your Romed 7 (28 June 1862): 374-8.

[Trollope, Frances Elcanor]. "The Tale of Aune Margaret's Trouble: In Six Weckly Portions." All the Yar Romed 16 (14, 21, 28 July, 4, 1 1,18 August 1 866): 1-6, 25-31, $49-55,73-9,97-104,121-5$.

Wills, Katc. "The unseen Charles Dickens: read the excoriaring essay on Victorian powerty that no-one knew he had written." Independent 13 July 2015. Web. 